\title{
A Mixed Methods Bibliometric Investigation of the World Review of Entrepreneurship, Management and Sustainable Development: from qualitative to quantitative data
}

Peer-reviewed version forthcoming in World Review of Entrepreneurship, Management and Sustainable Development

\author{
Giacomo Marzi \\ Department of Business and Economics, \\ Università di Pisa, \\ Pisa, Italy \\ Email: giacomo.marzi@unifi.it
}

\section{Riccardo Rialti}

Department of Business and Economics, Università di Pisa,

Pisa, Italy

Email: riccardo.rialti@gmail.com

\section{Marina Dabić}

Faculty of Economics and Business, University of Zagreb,

Zagreb, Croatia

and Nottingham Business School,

Nottingham Trent University,

Nottingham, UK

Email: marina.dabic@ntu.ac.uk

\author{
Andrea Caputo \\ Lincoln International Business School, \\ University of Lincoln, \\ Lincoln, UK \\ Email: acaputo@lincoln.ac.uk
}

\begin{abstract}
This article offers a complete overview of the World Review of Entrepreneurship, Management and Sustainable Development (WREMSD) from 2005 to 2015 . The article employs an innovative mixed method, based on a bibliometric analysis of the Journal and an in-depth interview with the editor Prof. Leo Paul Dana about the journal, his academic and personal life. By using SCOPUS data, the analysis maps the knowledge produced and disseminated by
\end{abstract}


the journal revealing the most cited papers and most prolific authors. By also presenting a keywords correlation analysis, the paper shows the main streams of research covered by the Journal and their evolution. Although the objective of mapping the knowledge in WREMSD this paper offers an example of application of a mixed method to bibliometric studies, methodological implications are discussed.

Keywords: Bibliometric, Scientometric, Keywords, Mixed Methods, Qualitative, Quantitative, Keywords Clustering, Journal Impact, Journal Knowledge Structure, Management, Entrepreneurship, Interview, Scopus.

Acknowledgments: The authors gladly thank Prof. Leo Paul Dana for the time he has dedicated to us to complete our research. Specifically, we would like to thank him for the precious insights he has provided us about his life and career and, moreover, concerning the evolution of the journal.

Reference to this paper should be made as follows: Author. (xxxx) 'Title', World Review. $x x x x x x x x x x x x \times x x x x x x x x x x x$,

\section{Biographical notes:}

Giacomo Marzi is a Ph.D. student in Management and Business Administration from the University of Pisa (IT), and his research is mainly focused on innovation management, entrepreneurship and bibliometric. He has authored and coauthored a number of papers that appeared in journals such as Business Process Management Journal and the International Journal of Innovation and Technology Management. His work has also been presented at conferences such as the Academy of Management and the European Academy of Management. Giacomo is also a Visiting Scholar in the University of Zagreb (HR).

Riccardo Rialti is a Ph.D. student in Management and Business Administration from the University of Pisa (IT). His main research interest is entrepreneurship, specifically, how entrepreneurial characteristics relate to firm image and performance. Further interests include business ethics, branding, and digital technologies for communication. His work has also been presented at several national and international conferences.

Marina Dabic is a Full Professor of International Business and Entrepreneurship. She has edited several special issues on innovation, internationalisation, HRM and transfer technology. She published more than 50 papers appeared in wide variety of international journals including JIBS, JWB, JBE, IMR, EMJ, TBR, IJPDLM EBR and MIR among others. In her carrier, she achieved success in working on numerous projects, has been reviewer for Horizon 2020 projects as well as the grant holder of projects financed by European commission.

Andrea Caputo is Senior Lecturer in Strategy at the Lincoln International Business School (UK) and a member of the Scientific Committee of the Fondazione Bruno Visentini (Rome, Italy). He received his $\mathrm{PhD}$ in Management from the University of Rome Tor Vergata (IT). He has also been a Visiting scholar at the University of Queensland Business School (AU), at The George Washington School of Business (USA), and at the University of Pisa (IT). His main research interests are related to negotiation, decision-making, entrepreneurship and strategic management. His work has been presented at many international conferences, such as the AOM, EURAM, BAM and the International Association for Conflict Management. 


\section{Introduction}

The World Review of Entrepreneurship, Management and Sustainable Development (WREMSD) is a double-blind peer-reviewed journal published by the Geneva $(\mathrm{CH})$ based academic publisher Inderscience (Inderscience.com, 2016). Currently, the Editor in Chief is Prof. Dr. Leo Paul Dana. Among the main promoters of the journal creation we cite Prof. Dr. M. Dorgham and Prof. Dr. Allam Ahmed. The latter has also been the first Editor in Chief of the journal.

The history of WREMSD traces back to 2005, when it was founded to provide an in-depth analysis of the issues related to global competitiveness, local entrepreneurship and sustainable development. According to the founders' intentions, the principal aim of the journal is to "help local people to adapt and apply modern managerial practices to their local settings and improve their decision-making process and competitiveness" (Amhed, 2005, p.3). Moreover, one of the principal objectives of WREMSD "is to bring together the knowledge, skills and experience on these issues across the world and therefore benefit a wide range of universities, research centres, individuals, entrepreneurs, small businesses, governmental departments and policy makers worldwide" (Inderscience.com, 2016). Specifically, Dr. Allam Ahmed has identified entrepreneurship, management and sustainable development as WREMSD's main area of interest (Ahmed, 2005).

The journal covers various topics, especially those regarding environmental challenges for business and management, corporate governance, business ethics, corporate social responsibility, foreign direct investments, international trade, multicultural entrepreneurship, and SMEs relates issues (Inderscience.com, 2016).

From 2005 to 2015, the journal has published 270 peer-reviewed papers. In particular, two issues were published in 2005, three in 2006 and four from 2009 to 2016. The increase of the number of issues from 4 to 6 in 2017 is among the principal objectives of the current editorial board (Inderscience.com, 2016). The data given by the current editor Prof. Dr. Leo Paul Dana regarding the submissions to WREMSD in the last three years are shown in the table below (Table 1$)^{1}$.

\footnotetext{
${ }^{1}$ Please note that data for 2016 are updated to 10th October 2016
} 
Insert Table 1 About Here

Despite these valuable achievements, the journal in 2011 had risked being stopped due to the Christchurch earthquake in New Zealand where the current editor lived and worked. However, he continued to work as an editor for WREMSD. He received the Leading Editor Award for Excellence, for coping with the circumstances.

The present research begins with an interview of the editor Prof. Dr. Leo Paul Dana where several interesting topics about his personal life emerge. Through the words of the editor it is possible to gather a practical example of academic entrepreneurship and personal resilience.

Following the interview, a bibliometric analysis of WREMSD is presented and then the paper shows the knowledge structure of the journal by analysing the published papers authors' keywords through the VOS correlation method.

Finally, this work aims to highlight and to give an example of several methodological insights regarding the usefulness of a bibliometric mixed method approach. In fact, combining an interview, which produces qualitative data, with a statistical analysis offers wider comprehension about what is really behind a journal and its knowledge structure.

WREMSD is particularly suitable to achieve our methodological aim because it publishes topics that are sometimes skipped by mainstream journals, offering a wide set of streams inside Entrepreneurship, Management and Sustainable Development. Moreover, the editor has a particular life story that made it interesting to delve into some topics such as academic entrepreneurship and resilience, giving the opportunity to illustrate the "soul" behind the journal. Thus, this mixed method approach helps both to show the human and the scientific side of the journal.

\section{An interview with the editor Prof. Dr. Leo Paul Dana}

Before undertaking the bibliometric exploration of WREMSD, to gather some qualitative information concerning the journal, the authors have interviewed the editor Prof. Dr. Leo Paul Dana. The initial interview was semi-structured and composed of 16 questions.

\subsection{Methodological notes about the interview process}


Albeit mostly used in marketing research, methodological literature argues that in depth semi-structured interviews can be fundamental to obtain additional narrative information (Ritchie et al., 2013). Moreover, semistructured interviews allow scholars to analyse emotions and experiences of the interviewed individual (Yin, 2013).

To formulate the interview plot, authors have first taken into consideration examples of interviews coming from the major international business journals such as Harvard Business Review, Financial Times, and Fortune. After this scanning, a preliminary set of questions was prepared. However, to pursue the scope of the interview, the set of questions was adapted and checked using other interviews with editors in academic fields such statistics, chemistry and medicine (Fischer and Zwett, 2015; Nahai and Bernard, 2016; Schmidt-Radde, 2016). Finally, the interview guide was revised by an external independent reviewer.

Particularly to the interview plot, (1) first, we asked three questions concerning the initial editorial board of WREMSD; (2) second, we investigated with three questions, which is the scope of the journal; (3) third, we asked two questions concerning the impact of digitalisation on the journal; (4) fourth, we asked seven technical question concerning WREMSD; finally, (5) we inquired about the greatest challenge WREMSD has ever faced. Moving from this last question, we asked the editor some additional, and not initially scheduled, questions about his personal experience during the 2011 Christchurch Earthquake. In the end, the interview became composed of 20 open questions. The interview occurred on $8^{\text {th }}$ October 2016. The structure of the interview is shown in the Appendix.

\subsection{The results of the interview with Prof. Dr. Leo Paul Dana}

On 22 February 2011 at 12:51 p.m. local time a severe earthquake occurred in Christchurch, New Zealand with a magnitude of 6.3 on the Richter scale. As a result, unfortunately, 185 people died and a vast amount of buildings were either damaged or destroyed. In these circumstances, the current editor used one computer provided by the Red Cross to manage WREMSD journal. The Christchurch earthquake has been deemed by the editor as the greatest challenge ever, threatening WREMSD survival; we start our conversation from that event. 
Prof. Dana, you told us that after the earthquake you still continued to work as editor of WREMSD. How did you manage it?

The Red Cross was very good to us. We had no power and no running water, but I had access to a shared computer from which I could send manuscripts to reviewers around the world-nothing was easy.

You worked hard for many years establishing yourself as a researcher with publications in major journals. You had tenure and yet you are no longer at the University of Canterbury?

Yes, I had tenure but an earthquake can prompt many changes. Our offices were beyond limits due to earthquake damage and we taught in tents; we were losing students. I was nominated for the best teaching award, but eventually circumstances caused the university to downsize considerably. I am no longer there.

How did you, a successful academic entrepreneur, absorb the pain and loss from the earthquake but then face the challenge in order to apply your energy and strategy to overcome, using available "resources" to make life liveable?

There were moments during which nothing seemed liveable, but how I coped is a story that began in 1962, when my parents received a telegram indicating that a long-distance phone-call had been reserved with Bell Canada, and my mother would talk with her sister Sophie Charlotte for the first time since 1951. They had been kept apart not by quarrel, but rather by the lack of globalisation and technology. During the phone-call, it was confirmed that my aunt would soon land at Montreal's (then) new Dorval Airport.

Many years before that, Sophie Charlotte accompanied her mother Naomi - my maternal grandmother - to the dentist. Her dentist was a Dr. Tadros, whose son Fayez had recently graduated with a degree in dental surgery, from Lebanon. Fayez set up his dental practice in Cairo, Sophie fell in love with him, and they got married and lived happily ever aftersort of. In 1962, they decided to leave the United Arab Republic, as Egypt was known at the time. They were coming to Canada where they would start a new life, hopefully a better life. A detail worth mentioning is that although Dr Fayez Tadros had practised dental surgery in Cairo for about 30 years, his degree was not recognised in Canada. He would therefore become a freshman again, a first year student at the Université de Montréal; my aunt, almost 50 years old, would find a job to support her family.

I asked my mother whether it was fair that an experienced dentist be required to study dentistry from scratch. She kindly replied that before 
WWI, our family was very wealthy, but thereafter there was much uncertainty as to where the next meal would come from. I would learn that events in life do not always appear to be fair.

Given our financial situation, my father worked very hard and I seldom saw him. My mother encouraged me to study, and I did. Being accepted at McGill University was not an option; it was expected of me. When I was an undergraduate I practised so much for the GMAT that I performed quite well, so much so that I was asked during my MBA admissions interview how I managed to cheat and not get caught.

I began lecturing part-time at Concordia University in 1984; the students liked me and petitioned that I be hired to teach a subsequent course in 1985. I was also working in the family business, for which in 1985 we were looking to recruit and so I went to the McGill employment centre to interview prospective applicants; there I met a gentleman seeking to hire a full-time lecturer for Acadia University. He was a better salesman than I, and he hired me to teach in Nova Scotia.

I completed a PhD and eventually became deputy director of the International Business MBA at Nanyang Business School.

After the earthquakes, it was very humbling to have nowhere I could call home. We lost our family business, our home, the orchard, the vineyard, and my job. My mother died after being crushed in an aftershock. I lost my energy too; when my spine was severely injured I lost the ability to walk.

It all seemed unbearable, but I remembered that my uncle-formerly a successful and wealthy dentist - arrived in Canada with a baggage allowance of 20 kilos, leaving his fortune behind. As his credentials were not recognised, in Canada, he was in his fifties when he again became an undergraduate. Once again, he learned dentistry from scratch, but he was soon teaching dentistry and in 1967 he established a successful practice. He wanted a good future for his son, my cousin Sobhi - and made it possible. My cousin Sobhi became a very successful entrepreneur.

I think that was an important lesson for me. I was not the first to be pushed back in life. I lost much - even the ability to walk - but it was important to get back on my feet. I owed it to my children.

How your experience regarding the earthquake influenced the journal? I realised the importance of delegation.

Can you tell us the future streams in which journal would like to go? A goal for the future is to increase the focus on sustainable management. I would like to use this opportunity also to invite readers to submit papers on sustainable development, both in developed and developing counties. 
With this excerpt of the interview with the editor Leo Paul Dana, the authors would like to give a more personal and human perspective to the journal, highlighting that behind the academic scientific production there are personal stories of success, resilience, and courage.

Resilience, which has traditionally been defined as the human and organisational capability to recover and succeed after unexpected events disrupting initial conditions (Bullough et al., 2014), hence, emerges has a fundamental trait in what concerns both academic production and entrepreneurship (Krueger, 2008). Specifically, resilient people and organisations are deemed able to overcome initial increasing complexity and difficulties by recovering more quickly from shocks and by adapting to changing scenarios (Tilley and Parrish, 2006). In this sense, by our personal interview with the editor, we have been able to obtain some more information about the main scopes of the journal. Thus, personal experiences affecting those scopes have emerged from the editor's words. In particular, the interview has added some relevant insights on the guiding values of the journal and the attention from the editor and editorial board toward minorities, sustainable development and entrepreneurship in extreme conditions (Dana, 1995; Papadopoulos et al., 2014; Sethna et al., 2014).

Building on the results of this interview and on journal general data, hence, it has been possible to better interpret quantitative data emerging from the bibliometric analysis conducted in the following paragraphs and to contextualise them.

\section{Bibliometric Journal Analysis}

To analyse the knowledge base of the journal, the second part of the present research concerns a bibliometric analysis of WREMSD. Indeed, differentiating from systematic literature reviews (e.g., Abatecola et al, 2013; Caputo, 2013), bibliometric studies have shown their effectiveness in a broad range of fields as management (Podsakoff et al., 2008), expatriates (Dabic et al., 2015), strategic management (Furrer et al., 2008; Dabic et al., 2014; Gonzalez-Loureiro et al., 2015), entrepreneurship (Landström et al., 2012), operations management (Hsieh \& Chang, 2009) and innovation (Fagerberg et al., 2012) helping scholar to sort out the scientific knowledge base.

\subsection{Methodological notes about bibliometric analysis}


Regarding the sample selection, Scopus database has been chosen. The data covers all the publication of the journal from the first issue to 2015 included. All data we have gathered, including the number of papers and total citations, are updated as of 23rd June 2016. Data are analysed using Microsoft Excel 2016 and Rapid Miner Studio 7.3 Educational Edition.

\subsection{Paper Overview}

The following Table (Table 2), shows years, number of papers (N.P.) and percentage variation compared to previous year (P.V.).

\section{Insert Table 2 About Here}

In this sense, a graphical illustration better represents the magnitude of the phenomena. Data collected showed the following distribution (Figure 1) over the years. Apart from the very first year, when only 12 papers were published, the year with the greater number of contributions has been 2014 with 31 papers. In 2015, instead, a total of 25 papers have been published. The number of published papers is set to increase in 2017 as a consequence of the editorial board's decision to add two additional issues per year starting in 2017.

Insert Figure 1 About Here

Concerning the overall number of citations, the 270 papers published in WREMSD have been totally cited 333 times. According to our data, 2007 has been the best year in regard to citations with a grand total of 69 citations. Instead, so far, 2015 has been the worst. Nevertheless, the fact that most WREMSD papers published in 2015 haven't been cited may be considered influenced by the fact that citing articles are still under review or in press. Hence, data for 2015 citation may appear lower than reality for at least all of 2016. No precise pattern could be identified in regard of the citations' trend (see table 3 and figure 2). As a consequence, with the increase in the 
number of issues the editors expect a growth in the number of citations due to the greater number of published researches.

Insert Table 3 About Here

Insert Figure 2 About Here

Among the papers published in WREMSD, the paper "The Effects of Culture Clash on International Mergers in the High Tech Industry", edited by Weber and colleagues (2012), emerges as the most cited paper on Scopus collection totalling 17 citations.

"Research Valorisation Through Spin-Off Ventures: Integration of Existing Concepts and Typologies" edited by Cleyn and Braet (2009), which totals 12 citations, is the second most cited paper published in WREMSD. Moreover, another 4 more papers outnumber 10 citations. Specifically, those latter are the ones edited by Rentizelas and colleagues (2007), Tilley and Parrish (2006), Diamantas and colleagues (2007) and Mgaya and Kitindi (2008) (see Table 4).

Insert Table 4 About Here

Sustainable entrepreneurship (Ahmed and McQuaid, 2005; Tilley and Parrish, 2006), external factors affecting positively and negatively entrepreneurship (Wu, 2007; De Cleyn and Braet, 2009; Wu and Liang, 2012), SMEs (Dasanayaka and Sardana 2010), and CSR (Nikolaou and Evangelinos, 2009; Amran and Devi 2010) are the most relevant topics of the most cited papers. Concerning the topics explored by papers published in WREMSD, those topics may be deemed similar to other Inderscience journals related to WREMSD like International Journal of Business and Globalisation (IJBG) (Dana and Dana, 2008; Nicolopoulou and Karatas- 
Ozkan, 2009) or International Journal of Entrepreneurship and Small Business (IJESM) (Dana and Dana, 2005; Ratten et al., 2007; Knez-Riedl, 2008).

\subsection{Author Overview}

The second part of the present analysis involves authors. Table 5 shows the most prolific authors with at least 2 papers including co-authorship. Prof. Peter Jones, currently an emeritus professor of management at Gloucestershire University, have emerged as the most prolific author totalling 4 papers published as first author in WREMSD from 2010 to 2015.

\section{Insert Table 5 About Here}

In regards to the authors cited more than 5 times, as it is possible to observe in table 6 , the ranking strictly follows the one of the most cited papers.

Insert Table 6 About Here

\subsection{Countries Overview}

As the majority of journals require Academic English language, the majority of contributions to WREMSD are from the United Kingdom. The United States of America and Mediterranean European countries such as Italy, Portugal, Greece, Cyprus and Spain are instead the following countries. Moreover, coherently with the scope of the journal, an elevated number of recent contributions come from authors from emerging economies such as Malaysia, UAE, Kazakhstan and Nigeria, allowing scholars from emerging countries to publish their researches in a valuable journal (see table 7). 
Insert Table 7 About Here

\section{Keyword Analysis}

After the presentation of papers, authors, and countries who published in WREMSD, to achieve the objective of visualising research streams by an extensive number of papers, we used the text-mining routine VOSviewer 1.6.5 (Van Eck and Waltman, 2010).

The map built by the text-mining routine is a plot in which the terms' distance can be interpreted as an indication of the relatedness of the terms. The smaller distance between terms, the stronger the terms are related to each other. The terms' relatedness is determined by co-occurrences in documents (Van Eck et al., 2010). After the analysis of terms, the next step involves the cluster analysis (Figure 3) the measure of intra- and intercluster diversity with the aim of better understanding the degree of knowledge base diversity within each cluster (Van Eck and Waltman, 2014). Finally, to settle to what extent a certain cluster is more diverse than another one the script performs a t-test to examine the differences in their diversity (Van Eck and Waltman, 2009; Waltman et al., 2010).

The keyword analysis concerns the main authors' keywords that appear (e.g. occurrences-OC.) at least three times in the dataset. The figures below show the results of the analysis. Specifically, Figure 3 and Table 8 show the keyword density. Instead Figure 4 and Table 9 respectively show and explain the keyword cluster aggregation.

Insert Figure 3 About Here

Insert Table 8 About Here 
As it is possible to observe in figure 3, Entrepreneurship (32 OC) and Sustainable Development (20 OC) represent the principal keywords used by WREMSD authors. Moreover, it is also possible to observe how the keywords SMEs, Internationalisation and Family Business emerge as the most used in conjunction with the aforementioned two most used ones (Moskowitz, 2008; Smith, 2011).

This phenomenon is clearly understandable considering the principal scopes of the journal. Apart from entrepreneurship and sustainable development, further, an additional focal point around the keywords corporate governance has emerged (6 occurrences- OC.). The keywords mostly used in conjunction with Corporate Governance are Institutional Theory and Corporate Social Responsibility (Amran and Devi, 2007; Khadaroo and Shaikh, 2007).

In addition, from our analysis it emerges how in recent times there has been a growing number of contributions in WREMSD concerning entrepreneurial education (Białek-Jaworska and Gabryelczyk 2015; Rialti et al., 2017), ethnic entrepreneurship (Santini et al., 2011), female entrepreneurship (Ramadani et al. 2015), and entrepreneurship in developing countries (Ras and Vermeulen, 2012).

In regards to the literature stream to which they belong, those keywords may be grouped in eight clusters. Each cluster corresponds to a specific stream of literature (see Figure 4 and Table 9). The cluster characterised by the greatest number of keywords occurrences is the one composed by the keywords family business, growth, internationalisation, SMEs and competitiveness orbiting around the main keyword entrepreneurship.

Insert Figure 4 About Here

Insert Table 9 About Here

The red cluster (1) represents the area of competition, finance and performance related topics. In fact, one of the most important papers in this red cluster is written by Rentizelas and colleagues (2007); it proposes an 
innovative approach that merges optimisation and risk analysis through a Genetic Algorithm optimisation and Monte Carlo simulation and is one of the most cited papers in WREMSD.

The green cluster (2) represents the area of growth and entrepreneurship where the paper written by De Cleyn and Braet (2009), is one of the most representative. In fact, the authors clarify the differences between the concepts of 'spin-off' and 'spin-out' integrating several existing spin-off taxonomies, classifications and typologies in order to create a clear and complete framework for further research.

The blue cluster (3) is connected to the area of economic development, FDI and sustainable development. The most representative paper in this area is that written by $\mathrm{Wu}$ and Liang (2012) in which using data from Global Entrepreneurship Monitor, CIA's World Factbook and the 1997 Transparency International, they found that whole corruption and total entrepreneurial activity are negatively related. Its results are that more corruption is equal to less entrepreneurial activity which is equal to less economic growth, development and FDI.

The yellow cluster (4) represents the role of innovation, technology and knowledge in natural and societal environments. It is possible to refer to the paper written by Burrows and Omar (2007). which by studying the UK service industries have reduced their cost, introducing energy efficiency to their operations. It happened thanks to the actions of government and social groups that pushed companies to pursue efficiency and environmental attentions in all their actions.

The purple cluster (5) relates to the yellow one. However, the purple takes into consideration corporate social responsibility in a wider perspective. In fact, the paper wrote by Tilley and Parrish (2006) takes into consideration sustainable entrepreneurship as a potentially powerful tool in shifting socio-economic institutions, both private and public, toward an orientation that contributes to sustainable development. The paper stresses the challenges for the sustainable entrepreneurs and proposed a research agenda to support policies that effectively facilitate integration.

The light blue cluster (6) refers to the role of the culture in the organisations. For example, the paper by $\mathrm{Wu}$ (2007) examines the relationship between national culture and national entrepreneurial activity. The paper shows that individualism and total entrepreneurial activity are negatively related. Thus, it suggests that policy makers should create an environment and make policies that encourage collectivism to boost entrepreneurship.

The dark blue cluster (7) delves into the role of human resources in organisations. For example, the paper by Bresciani and colleagues (2012), 
studies the relationship between human resource management and organisational performance in the Italian hospitality sector. The findings stress the need for an inclusive approach to management, within an extensive methodically developed strategic context, as the means to long term success.

Finally, the papers in the brown cluster (8) analyse the role of spirituality in management. As an example, the paper from Ungvári-Zrínyi (2014) analyses spirituality as motivation for a socially responsible entrepreneurship. In particular, he combined the work of several philosophers and psychologists trying to disclose the deepest sources of everyday creativity and meaningful life in entrepreneurial and economic activity.

\section{Conclusions}

With this paper, we have taken into consideration the most relevant papers published by WREMSD over the last decade. Moreover, we have also explored which authors have been the principal contributors and their countries of origin. In order to do so, the research string has taken into consideration all the papers published by WREMSD, and we have identified the most cited ones and the principal contributors. The main contributions of this paper are both methodological and theoretical.

Regarding methodology, the present research contributes to the scientific community with a valuable example of a bibliometric mixed method approach. Indeed, by complementing the bibliometric analysis with a qualitative interview, we were able to further investigate topics that were not possible to reach by only a bibliometric approach. Specifically, our scope was to integrate a narrative-based approach with a statistical-based approach to show a wider view about the journal and the "personal touch" behind it. Indeed, this was only possible by the addition of a preliminary interview to the bibliometric analysis. Hence, we suggest future researchers to first consider qualitative aspects deriving from interviews to better interpret quantitative data in regards tp bibliometric researches.

In terms of the theoretical implications, we explored the knowledge base of one of the emerging entrepreneurship journals. Specifically, we have first explored the principal papers published by WREMSD and the literature trajectories of such journal. Moreover, through our interview with the editor Prof. Leo Paul Dana we have analysed how personal experiences may influence significantly the scientific production of scholars. Literature trajectories of journals have appeared influenced too. Topics such as academic entrepreneurship and resilience, in fact, often derive from 
personal experiences and real world events triggering the life of authors. In addition, through the narrative of this research it has emerged how entrepreneurship, literature production on entrepreneurial resilience and personal resilience experiences are often interrelated. Following the interview, the bibliometric analysis allowed us to present, through the papers' database, a snapshot of the main streams of research, and their impact on the scientific community, of WREMSD. In details, data have shown how entrepreneurship and sustainable development are key elements characterising papers published by WREMDS through its history. Moreover, the keyword analysis highlighted the streams inside WREMSD where scholars have focused their attention. In particular, the analysis shows that, coherently with the scopes of the journal, entrepreneurship and sustainable development play a major role in WREMSD. Such topics are followed by internationalisation and innovation, which are playing a relevant role too. The other topics are following with a relevant difference. The evidence is also confirmed by the analysis of most cited papers.

Recently, over the last years WREMSD has considered several special issues regarding prevalently entrepreneurship, entrepreneurial education and sustainable development. Moreover, currently the journal is expecting submissions on the last activated special issue on "The Future Promise of Internet of Things (IoT) and Smart Cities: Governance, Entrepreneurship and Innovation Management". Hence, a growing attention is being paid to effects of technological evolution impacts on management and entrepreneurship. Moving from this preliminary special issue, in the future WREMSD should continue to focus on related topics and on emerging issues such as for example migrants' entrepreneurship and entrepreneurs in developing countries. In this sense, we highly encourage future scholars to submit papers related to entrepreneurship to WREMSD to bring the journal forward in the next 10 years.

\section{References}

Abatecola, G., Caputo, A., Mari, M. and Poggesi, S. (2013). Real Estate Management: Past, Present and Future Research Directions. International Journal of Globalisation and Small Business, 5 (1/2), 98113.

Ahmed, A. (2005). Welcome to WREMSD. World Review of Entrepreneurship, Management and Sustainable Development, 1(1), 15. 
Ahmed, A., \& McQuaid, R. W. (2005). Entrepreneurship, Management, and Sustainable Development. World Review of Entrepreneurship, Management and Sustainable Development, 1(1), 6-30.

Amran, A. B., \& Devi, S. S. (2007). Corporate Social Reporting in Malaysia: an Institutional Perspective. World Review of Entrepreneurship, Management and Sustainable Development, 3(1), 2036.

Białek-Jaworska, A., \& Gabryelczyk, R. (2015). Stimulating Entrepreneurship by Teaching Accounting: Concept and Implementation. World Review of Entrepreneurship, Management and Sustainable Development, 11(2-3), 137-155.

Bresciani, S., Thrassou, A., \& Vrontis, D. (2012). Human resource management-practices, performance and strategy in the Italian hotel industry. World Review of Entrepreneurship, Management and Sustainable Development 3, 8(4), 405-423.

Bullough, A., Renko, M., \& Myatt, T. (2014). Danger Zone Entrepreneurs: The Importance of Resilience and Self-Efficacy for Entrepreneurial Intentions. Entrepreneurship Theory and Practice, 38(3), 473-499.

Burrows, M., \& Omar, M. (2007). Sustainable energy policies as a source of competitive advantage in the UK service industry. World Review of Entrepreneurship, Management and Sustainable Development, 3(3-4), 231-250.

Caputo, A. (2013). A Literature Review of Cognitive Biases in Negotiation Processes. International Journal of Conflict Management, 24(4), 274398.

Dabic, M., Gonzales-Loureiro, M., \& Furrer, O. (2014). Research on the strategy of multinational enterprises: Key approaches and new avenues. Business Research Quarterly, 17(2), 129-148

Dabic, M., Gonzales-Loureiro, M., \& Harvey, M. Evolving research on expatriates: what is 'known' after four decades (1970-2012). International Journal of Human Resource Management. 26 (3), 316-337

Dana, L. P. (1995). Entrepreneurship in a Remote Sub-Arctic Community. Entrepreneurship Theory and Practice, 20(Fall), 57-72.

Dana, L. P., \& Dana, T. E. (2005). Expanding the Scope of Methodologies Used in Entrepreneurship Research. International Journal of Entrepreneurship and Small Business, 2(1), 79-88. 
Dana, L. P., \& Dana, T. E. (2008). Ethnicity and Entrepreneurship in Morocco: A Photo-Ethnographic Study. International Journal of Business and Globalisation, 2(3), 209-226.

Dasanayaka, S. W., \& Sardana, G. D. (2010). Development of SMEs Through Clusters: A Comparative Study of India, Pakistan and Sri Lanka. World Review of Entrepreneurship, Management and Sustainable Development, 6(1-2), 50-70.

De Cleyn, S. H., \& Braet, J. (2009). Research Valorisation Through SpinOff Ventures: Integration of Existing Concepts and Typologies. World Review of Entrepreneurship, Management and Sustainable Development, 5(4), 325-352.

Diamantas, V. K., Kirytopoulos, K. A., \& Leopoulos, V. N. (2007). Project's Duration Prediction: Traditional Tools or Simulation?. World Review of Entrepreneurship, Management and Sustainable Development, 3(3-4), 317-333.

Fagerberg, J., Fosaas, M., \& Sapprasert, K. (2012). Innovation: Exploring the knowledge base. Research Policy, 41(7),1132-1153.

Fisher, N. I., \& Zwet, W. R. (2015). An Interview with Jae C. Lee. International Statistical Review, 83(3), 371-404.

Furrer, O., Thomas, H. \& Goussevskaia, A. (2008). The structure and evolution of the strategic management field: A content analysis of 26 years of strategic management research, International Journal of Management Reviews, 10(1), 1-23.

Gonzalez-Loureiro, M., Dabic, M., \& Furrer, O. (2015). A content and comparative analysis of strategic management research in the Baltic area: A research agenda for qualitative studies. Baltic Journal of Management, 10(2), 243-266.

Hsieh, P. N., \& Chang, P. L. (2009). An Assessment of World-Wide Research Productivity in Production and Operations Management. International Journal of Production Economics, 120(2), 540-551.

Inderscience.com (2016). World Review of Entrepreneurship, Management and Sustainable Development. Accessed 11/10/2016, URL: http://www.inderscience.com/jhome.php?jcode=wremsd\#moredesc

Khadaroo, I., \& Shaikh, J. M. (2007). Corporate Governance Reforms in Malaysia: Insights from Institutional Theory. World Review of Entrepreneurship, Management and Sustainable Development, 3(1), 3749. 
Knez-Riedl, J. (2008). The Development of Environmental Responsibility amongst Slovenian SMEs. International Journal of Entrepreneurship and Small Business, 6(1), 103-113.

Krueger, N. F. (2008). Entrepreneurial Resilience: Real \& Perceived Barriers to Implementing Entrepreneurial Intentions. Available at SSRN 1155269. Retrieved on 11/11/2016 and freely available at https://papers.ssrn.com/sol3/papers.cfm?abstract $\mathrm{id}=1155269$

Landström, H., Harirchi, G., \& Aström, F. (2012). Entrepreneurship: Exploring the Knowledge Base. Research Policy, 41(7), 1154-1181.

Mgaya, K. V., \& Kitindi, E. G. (2008). IT Skills of Academics and Practising Accountants in Botswana. World Review of Entrepreneurship, Management and Sustainable Development, 4(4), 366-379.

Moskowitz, S. L. (2008). Determinants of the Internationalisation of European SMEs: Inward Outward Linkages, the 'Stage' Theory of Global Expansion and the Role of the European Union in the Textiles and Apparel Industry. World Review of Entrepreneurship, Management and Sustainable Development, 4(2-3), 125-146.

Nahai, F., \& Bernard, E. S. (2016). 20th Anniversary Interview With ASJ Editor-in-Chief Dr Foad Nahai. Aesthetic Surgery Journal, 36(1), 119121.

Nikolaou, I. E., \& Evangelinos, K. I. (2008). Towards a Generally Accepted CSR Accounting Framework: a Literature Mapping. World Review of Entrepreneurship, Management and Sustainable Development, 5(1), 2641.

Nicolopoulou, K., \& Karatas-Ozkan, M. (2009). CSR and Social Entrepreneurship: Future Global Opportunities and Challenges in Corporate Community Involvement strategies. International Journal of Business and Globalisation, 3(2), 173-187.

Papadopoulos, I., Trigkas, M., Karagouni, G., \& Papadopoulou, A. (2014). The Contagious Effects of the Economic Crisis Regarding Wood and Furniture Sectors in Greece and Cyprus. World Review of Entrepreneurship, Management and Sustainable Development, 10(2-3), 334-351.

Podsakoff, P. M., MacKenzie, S. B., Podsakoff, N. P., \& Bachrach, D. G. (2008). Scholarly Influence in the Field of Management: A Bibliometric Analysis of the Determinants of University and Author Impact in the 
Management Literature in the Past Quarter Century. Journal of Management, 34(4), 641-720.

Ramadani, V., Hisrich, R. D., \& Gërguri-Rashiti, S. (2015). Female Entrepreneurs in Transition Economies: Insights from Albania, Macedonia and Kosovo. World Review of Entrepreneurship, Management and Sustainable Development, 11(4), 391-413.

Ras, P. J., \& Vermeulen, W. J. (2012). Innovative Business Cases in the South Africa Table Grape and Wine Industries: Developing the Concept of Empowerment Entrepreneurship. World Review of Entrepreneurship, Management and Sustainable Development, 8(4), 456-477.

Ratten, V., Dana, L. P., Han, M., \& Welpe, I. (2007). Internationalisation of SMEs: European Comparative Studies. International Journal of Entrepreneurship and Small Business, 4(3), 361-379.

Rentizelas, A., Tziralis, G., \& Kirytopoulos, K. (2007). Incorporating Uncertainty in Optimal Investment Decisions. World Review of Entrepreneurship, Management and Sustainable Development, 3(3-4), 273-283.

Rialti, R., Pellegrini, M. M., Caputo, A., \& Dabic, M. (2017). Entrepreneurial Education and Internationalisation of Firms in Transition Economies: a Conceptual Framework from the Case of Croatia. World Review of Entrepreneurship, Management and Sustainable Development.

Ritchie, J., Lewis, J., Nicholls, C. M., \& Ormston, R. (Eds.). (2013). Qualitative Research Practice: A Guide for Social Science Students and Researchers. Thousand Oaks, California: Sage.

Santini, C., Rabino, S., \& Zanni, L. (2011). Chinese Immigrants SocioEconomic Enclave in an Italian Industrial District: the Case of Prato. World Review of Entrepreneurship, Management and Sustainable Development, 7(1), 30-51.

Sethna, Z., Jones, R., \& Edwards, R. (2014). Entrepreneurial Species: Influences of Business and Social Contexts on Indigenous and NonIndigenous Types. World Review of Entrepreneurship, Management and Sustainable Development, 10(2-3), 267-295.

Schmidt-Radde, R. (2016). Interview with the Editor. ChemPlusChem, 81(1), 3-6.

Smith, R. (2011). The Role of Storyboards and Scrapbooks in Propagating Entrepreneurial Value in Family Business Settings. World Review of 
Entrepreneurship, Management and Sustainable Development, 7(3), 260-271.

Tilley, F., \& Parrish, B. D. (2006). From Poles to Wholes: Facilitating an Integrated Approach to Sustainable Entrepreneurship. World Review of Entrepreneurship, Management and Sustainable Development, 2(4), 281-294.

Ungvári-Zrínyi, I. (2014). Spirituality as motivation and perspective for a socially responsible entrepreneurship. World Review of Entrepreneurship, Management and Sustainable development, 10(1), 415.

Van Eck, N. J., \& Waltman, L. (2009). How to Normalize Cooccurrence Data? An Analysis of Some Well-Known Similarity Measures. Journal of the American Society for Information Science and Technology, 60(8), $1635-1651$.

Van Eck, N. J., \& Waltman, L. (2010). Software Survey: VOSviewer, a Computer Program for Bibliometric Mapping. Scientometrics, 84(2), 523-538.

Van Eck, N. J., Waltman, L., Dekker, R., \& van den Berg, J. (2010). A Comparison of Two Techniques for Bibliometric Mapping: Multidimensional Scaling and VOS. Journal of the American Society for Information Science and Technology, 61(12), 2405-2416.

Van Eck, N. J., \& Waltman, L. (2014). Visualizing Bibliometric Networks. In Measuring scholarly impact (pp. 285-320). Springer International Publishing.

Waltman, L., van Eck, N. J., \& Noyons, E. C. (2010). A Unified Approach to Mapping and Clustering of Bibliometric Networks. Journal of Informetrics, 4(4), 629-635.

Weber, Y., Tarba, S. Y., \& Rozen Bachar, Z. (2012). The Effects of Culture Clash on International Mergers in the High Tech Industry. World Review of Entrepreneurship, Management and Sustainable Development, 8(1), 103-118.

$\mathrm{Wu}$, S. (2007). The Relationship between National Culture and National Entrepreneurial Activity. World Review of Entrepreneurship, Management and Sustainable Development, 3(2), 127-141.

Wu, S., \& Liang, X. (2012). An Examination of the Relationship Between Corruption and Total Entrepreneurial Activity. World Review of 
Entrepreneurship, Management and Sustainable Development, 8(4), 478-489.

Yin, R. K. (2013). Case Study Research: Design and Methods. Thousand Oaks, California: Sage. 


\section{Appendix}

Table 10 Questions of semi-structured interview with Prof. Dr. Leo Paul Dana

\begin{tabular}{|c|c|}
\hline Macro-Area of the question & Question \\
\hline $\begin{array}{l}\text { A) WREMSD' EDITORIAL } \\
\text { BOARD }\end{array}$ & $\begin{array}{l}\text { 1) Who was the first editor in chief of World } \\
\text { Review of WREMSD? } \\
\text { 2) Who were the firm individuals composing the } \\
\text { editorial board when the journal has been created? } \\
\text { 3) Among the first members of the editorial board, } \\
\text { who were the promoters of the creation of the } \\
\text { journal? }\end{array}$ \\
\hline $\begin{array}{l}\text { B) WREMSD SCOPE AND } \\
\text { PRINCIPAL } \\
\text { CHALLENGES } \\
\text { ADDRESSED }\end{array}$ & $\begin{array}{l}\text { 4) Which have been the principal motivations } \\
\text { underlying the creation of the journal? } \\
\text { 5) Does the journal have external institutions } \\
\text { sponsoring it? How much are those for the journal } \\
\text { survival? } \\
\text { 6) Which are the principal scopes of WREMSD? }\end{array}$ \\
\hline $\begin{array}{l}\text { C) IMPACT OF } \\
\text { DIGITALISATION } \\
\text { WREMSD }\end{array}$ & $\begin{array}{l}\text { 7) Have digitalisation and the evolution of web- } \\
\text { based platforms affected the traditional procedures } \\
\text { of paper submission and reviewing? } \\
\text { 8) When has the journal been indexed Scopus? }\end{array}$ \\
\hline $\begin{array}{l}\text { D) TECHNICAL } \\
\text { QUESTIONS }\end{array}$ & $\begin{array}{l}\text { 9) Has WREMSD ever been published by other } \\
\text { publishers apart from Inderscience? } \\
\text { 10) Has the number of yearly published } \\
\text { contributions increased over the time? If yes, how } \\
\text { much approximately? } \\
\text { 11) Why will you increase the number of volumes in } \\
\text { 2017? } \\
\text { 12) Which are the main communication channels } \\
\text { used for the promotions of special issues? } \\
\text { 13) Does WREMSD only considered submitted peer } \\
\text { reviewed papers or also editor reviewed paper of } \\
\text { contributions directly requested by members of the } \\
\text { editorial board? } \\
\text { 14) Which is WREMSD rejection rate? } \\
\text { 15) Can you tell us the future streams in which } \\
\text { journal would like to go? }\end{array}$ \\
\hline $\begin{array}{l}\text { E) PRINCIPAL } \\
\text { CHALLENGES EVER } \\
\text { FACED BY WREMSD }\end{array}$ & $\begin{array}{l}\text { 16) Which has been the biggest challenge that } \\
\text { WREMSD has ever confronted? }\end{array}$ \\
\hline $\begin{array}{l}\text { E.1) PERSONAL } \\
\text { QUESTIONS } \\
\text { (or additional questions } \\
\text { about editor private } \\
\text { experience) }\end{array}$ & $\begin{array}{l}\text { 17) You told us that after the earthquake you still } \\
\text { continue to work as editor of WREMSD. How you } \\
\text { managed it? } \\
\text { 18) You worked hard for many years establishing } \\
\text { yourself as a researcher with publications in major } \\
\text { journals. You had tenure and yet you are no longer } \\
\text { at the University of Canterbury? }\end{array}$ \\
\hline
\end{tabular}




\begin{tabular}{|l|l|}
\hline 19) How did you, as a successful academic \\
entrepreneur absorb the pain and loss from the \\
earthquake but then face the challenge in order to \\
apply your energy and strategy to overcome, using \\
available "resources" to make life liveable? \\
20) How your experience regarding the earthquake \\
influenced the journal?
\end{tabular}


A Mixed Methods Bibliometric Investigation of the World Review of Entrepreneurship, Management and Sustainable Development: from qualitative to quantitative data

\section{Tables and Figures}

Table 1 Detailed information about submissions for 2014, 2015, 2016

\begin{tabular}{|l|l|l|l|l|l|}
\hline Year & $\begin{array}{l}\text { Articles } \\
\text { Submitted }\end{array}$ & $\begin{array}{l}\text { Articles } \\
\text { Accepted }\end{array}$ & $\begin{array}{l}\text { Articles } \\
\text { Rejected }\end{array}$ & $\begin{array}{l}\text { Acceptance } \\
\text { Rate }\end{array}$ & $\begin{array}{l}\text { Throughput } \\
\text { Days }\end{array}$ \\
\hline 2014 & 50 & 24 & 25 & $48.00 \%$ & 195 \\
\hline 2015 & 106 & 57 & 47 & $53.77 \%$ & 71 \\
\hline 2016 & 66 & 18 & 26 & $27.27 \%$ & 105 \\
\hline Total & $\mathbf{2 2 2}$ & $\mathbf{9 9}$ & $\mathbf{9 8}$ & & \\
\hline
\end{tabular}

Table 2 Number of papers published every year in WREMSD

\begin{tabular}{|l|l|l|}
\hline Year & N.P. & Variation \\
\hline 2005 & 12 & ---- \\
\hline 2006 & 25 & $+108 \%$ \\
\hline 2007 & 26 & $+4 \%$ \\
\hline 2008 & 23 & $-12 \%$ \\
\hline 2009 & 25 & $+9 \%$ \\
\hline 2010 & 22 & $-12 \%$ \\
\hline 2011 & 23 & $+5 \%$ \\
\hline 2012 & 30 & $+30 \%$ \\
\hline 2013 & 28 & $-7 \%$ \\
\hline 2014 & 31 & $+11 \%$ \\
\hline 2015 & 25 & $-19 \%$ \\
\hline
\end{tabular}

Table 3 Number of citations totalled by paper published on WREMSD

\begin{tabular}{|l|l|l|}
\hline \multicolumn{1}{|c|}{ Year } & T.C. & \multicolumn{1}{c|}{ Variation } \\
\hline 2005 & 20 & --- \\
\hline 2006 & 49 & $+145 \%$ \\
\hline 2007 & 69 & $+41 \%$ \\
\hline 2008 & 21 & $-70 \%$ \\
\hline 2009 & 44 & $+110 \%$ \\
\hline 2010 & 17 & $-61 \%$ \\
\hline 2011 & 15 & $-12 \%$ \\
\hline 2012 & 46 & $+207 \%$ \\
\hline 2013 & 31 & $-33 \%$ \\
\hline 2014 & 21 & $-32 \%$ \\
\hline 2015 & 0 & --- \\
\hline
\end{tabular}


Table 4 WREMSD's most cited papers

\begin{tabular}{|c|c|c|c|c|}
\hline$\#$ & Authors & Title & Year & $\begin{array}{c}\text { Cited } \\
\text { by }\end{array}$ \\
\hline 1 & $\begin{array}{l}\text { Weber Y., } \\
\text { Tarba S.Y., } \\
\text { Bachar Z.R. }\end{array}$ & $\begin{array}{l}\text { The effects of culture clash on international } \\
\text { mergers in the high tech industry }\end{array}$ & 2012 & 17 \\
\hline 2 & $\begin{array}{l}\text { De Cleyn } \\
\text { S.H., Braet J. }\end{array}$ & $\begin{array}{l}\text { Research valorisation through spin-off } \\
\text { ventures: Integration of existing concepts and } \\
\text { typologies }\end{array}$ & 2009 & 12 \\
\hline 3 & $\begin{array}{l}\text { Rentizelas A., } \\
\text { Tziralis G., } \\
\text { Kirytopoulos } \\
\text { K. }\end{array}$ & $\begin{array}{l}\text { Incorporating uncertainty in optimal } \\
\text { investment decisions }\end{array}$ & 2007 & 11 \\
\hline 4 & $\begin{array}{l}\text { Tilley F., } \\
\text { Parrish B.D. }\end{array}$ & $\begin{array}{l}\text { From poles to wholes: facilitating an } \\
\text { integrated approach to sustainable } \\
\text { entrepreneurship }\end{array}$ & 2006 & 10 \\
\hline 5 & $\begin{array}{l}\text { Diamantas } \\
\text { V.K., } \\
\text { Kirytopoulos } \\
\text { K.A., } \\
\text { Leopoulos } \\
\text { V.N. }\end{array}$ & $\begin{array}{l}\text { Project's duration prediction: Traditional } \\
\text { tools or simulation? }\end{array}$ & 2007 & 10 \\
\hline 6 & $\begin{array}{l}\text { Mgaya K.V., } \\
\text { Kitindi E.G. }\end{array}$ & $\begin{array}{l}\text { IT skills of academics and practising } \\
\text { accountants in Botswana }\end{array}$ & 2008 & 10 \\
\hline 7 & Wu S. & $\begin{array}{l}\text { The relationship between national culture and } \\
\text { national entrepreneurial activity }\end{array}$ & 2007 & 8 \\
\hline 8 & $\begin{array}{l}\text { Ahmed A., } \\
\text { McQuaid } \\
\text { R.W. }\end{array}$ & $\begin{array}{l}\text { Entrepreneurship, management, and } \\
\text { sustainable development }\end{array}$ & 2005 & 6 \\
\hline 9 & $\begin{array}{l}\text { Rajab B., } \\
\text { Handley- } \\
\text { Schachler M. }\end{array}$ & $\begin{array}{l}\text { Corporate risk disclosure by UK firms: } \\
\text { Trends and determinants }\end{array}$ & 2009 & 6 \\
\hline 10 & $\begin{array}{l}\text { Dasanayaka } \\
\text { S.W.S.B., } \\
\text { Sardana G.D. }\end{array}$ & $\begin{array}{l}\text { Development of SMEs through clusters: A } \\
\text { comparative study of India, Pakistan and Sri } \\
\text { Lanka }\end{array}$ & 2010 & 6 \\
\hline 11 & $\begin{array}{l}\text { Wu S., Liang } \\
\text { X. }\end{array}$ & $\begin{array}{l}\text { An examination of the relationship between } \\
\text { corruption and total entrepreneurial activity }\end{array}$ & 2012 & 6 \\
\hline 12 & Sankaran M. & Micro credit in India: an overview & 2005 & 5 \\
\hline 13 & $\begin{array}{l}\text { Zheng P., Siler } \\
\text { P.A., } \\
\text { Giorgioni G. }\end{array}$ & $\begin{array}{l}\text { Sustaining growth in China's regions through } \\
\text { FDI }\end{array}$ & 2006 & 5 \\
\hline
\end{tabular}


A Mixed Methods Bibliometric Investigation of the World Review of Entrepreneurship, Management and Sustainable Development: from qualitative to quantitative data

\begin{tabular}{|c|c|c|c|c|}
\hline 14 & $\begin{array}{l}\text { Tziralis G., } \\
\text { Tatsiopoulos I. }\end{array}$ & $\begin{array}{l}\text { Prediction markets: An information } \\
\text { aggregation perspective to the forecasting } \\
\text { problem }\end{array}$ & 2007 & 5 \\
\hline 15 & $\begin{array}{l}\text { Amran A.B., } \\
\text { Devi S.S. }\end{array}$ & $\begin{array}{l}\text { Corporate Social Reporting in Malaysia: An } \\
\text { institutional perspective }\end{array}$ & 2007 & 5 \\
\hline 16 & $\begin{array}{l}\text { Koo L.C., Koo } \\
\text { H. }\end{array}$ & $\begin{array}{l}\text { Holistic approach for diagnosing, prioritising, } \\
\text { implementing and monitoring effective } \\
\text { strategies through synergetic fusion of } \\
\text { SWOT, Balanced Scorecard and QFD }\end{array}$ & 2007 & 5 \\
\hline 17 & $\begin{array}{l}\text { Muniapan B., } \\
\text { Shaikh J.M. }\end{array}$ & $\begin{array}{l}\text { Lessons in corporate governance from } \\
\text { Kautilya's Arthashastra in ancient India }\end{array}$ & 2007 & 5 \\
\hline 18 & $\begin{array}{l}\text { Nikolaou I.E., } \\
\text { Evangelinos } \\
\text { K.I. }\end{array}$ & $\begin{array}{l}\text { Towards a generally accepted CSR } \\
\text { accounting framework: A literature mapping }\end{array}$ & 2009 & 5 \\
\hline 19 & $\begin{array}{l}\text { Bresciani S., } \\
\text { Thrassou A., } \\
\text { Vrontis D. }\end{array}$ & $\begin{array}{l}\text { Human resource management-practices, } \\
\text { performance and strategy in the Italian hotel } \\
\text { industry }\end{array}$ & 2012 & 5 \\
\hline 20 & $\begin{array}{l}\text { Rossi M., } \\
\text { Vrontis D., } \\
\text { Thrassou A. }\end{array}$ & $\begin{array}{l}\text { Agro business in a changing competitive } \\
\text { environment - Campania firms' strategic, } \\
\text { marketing and financial choices }\end{array}$ & 2014 & 5 \\
\hline
\end{tabular}

Table 5 Most prolific authors

\begin{tabular}{|l|l|l|l|l|l|}
\hline$\#$ & Name & N. Paper & $\#$ & Name & N. Paper \\
\hline 1 & Jones P. & 4 & 13 & Lee H.-S. & 2 \\
\hline 2 & Bresciani S. & 3 & 14 & Mgaya K.V. & 2 \\
\hline 3 & Lee J.-W. & 3 & 15 & Mihoreanu L. & 2 \\
\hline 4 & Yazdanfar D. & 3 & 16 & Myllärniemi J. & 2 \\
\hline 5 & Caiazza R. & 2 & 17 & Omar M. & 2 \\
\hline 6 & Dasanayaka S.W.S.B. & 2 & 18 & Pollard D. & 2 \\
\hline 7 & De Cleyn S.H. & 2 & 19 & Roussakis E.N. & 2 \\
\hline 8 & El-Kafafi S. & 2 & 20 & Rudawska I. & 2 \\
\hline 9 & Franco M. & 2 & 21 & Seaman C. & 2 \\
\hline 10 & Hashim M.K. & 2 & 22 & Sohail M.S. & 2 \\
\hline 11 & Joshi M. & 2 & 23 & Tang Z. & 2 \\
\hline 12 & Karagouni G. & 2 & 24 & Wilton W. & 2 \\
\hline
\end{tabular}

Table 6 Most cited authors

\begin{tabular}{|l|l|l|l|l|l|}
\hline$\#$ & Name & $\begin{array}{l}\text { Times } \\
\text { Cited }\end{array}$ & $\#$ & Name & $\begin{array}{l}\text { Times } \\
\text { Cited }\end{array}$ \\
\hline 1 & Bachar Z.R. & 17 & 15 & Kitindi E.G. & 10 \\
\hline 2 & Tarba S.Y. & 17 & 16 & Leopoulos V.N. & 10 \\
\hline 3 & Weber Y. & 17 & 17 & Parrish B.D. & 10 \\
\hline
\end{tabular}




\begin{tabular}{|l|l|l|l|l|l|}
\hline 4 & Tziralis G. & 16 & 18 & Tilley F. & 10 \\
\hline 5 & Vrontis D. & 14 & 19 & $\begin{array}{l}\text { Dasanayaka } \\
\text { S.W.S.B. }\end{array}$ & 8 \\
\hline 6 & Wu S. & 14 & 20 & Sardana G.D. & 8 \\
\hline 7 & Braet J. & 13 & 21 & Bresciani S. & 7 \\
\hline 8 & De Cleyn S.H. & 13 & 22 & Ahmed A. & 6 \\
\hline 9 & Mgaya K.V. & 12 & 23 & $\begin{array}{l}\text { Handley- } \\
\text { Schachler M. }\end{array}$ & 6 \\
\hline 10 & Thrassou A. & 12 & 24 & Liang X. & 6 \\
\hline 11 & Kirytopoulos K. & 11 & 25 & McQuaid R.W. & 6 \\
\hline 12 & Rentizelas A. & 11 & 26 & Rajab B. & 6 \\
\hline 13 & Diamantas V.K. & 10 & 27 & Shaikh J.M. & 6 \\
\hline 14 & Kirytopoulos K.A. & 10 & & & \\
\hline
\end{tabular}

Table 7 Authors' countries of origin

\begin{tabular}{|l|l|l|l|l|l|}
\hline$\#$ & Country & $\begin{array}{l}\text { N. } \\
\text { Appearances }\end{array}$ & $\#$ & Country & $\begin{array}{l}\text { N. } \\
\text { Appearances }\end{array}$ \\
\hline 1 & $\begin{array}{l}\text { United } \\
\text { Kingdom }\end{array}$ & 50 & 15 & Malaysia & 9 \\
\hline 2 & $\begin{array}{l}\text { United } \\
\text { States }\end{array}$ & 46 & 16 & Spain & 8 \\
\hline 3 & Italy & 27 & 17 & Sweden & 8 \\
\hline 4 & Portugal & 18 & 18 & Australia & 7 \\
\hline 5 & Greece & 17 & 19 & Poland & 7 \\
\hline 6 & India & 17 & 20 & UAE & 7 \\
\hline 7 & Cyprus & 15 & 21 & Hungary & 6 \\
\hline 8 & Israel & 15 & 22 & Kazakhstan & 6 \\
\hline 9 & $\begin{array}{l}\text { New } \\
\text { Zealand }\end{array}$ & 15 & 23 & Nigeria & 6 \\
\hline 10 & Finland & 13 & 24 & Pakistan & 6 \\
\hline 11 & Germany & 12 & 25 & France & 5 \\
\hline 12 & Romania & 11 & 26 & Lithuania & 5 \\
\hline 13 & China & 10 & 27 & Saudi Arabia & 5 \\
\hline 14 & Japan & 9 & & & \\
\hline
\end{tabular}

Table 8 Keywords density in detail

\begin{tabular}{|c|l|c|c|l|c|}
\hline$\#$ & Label & Oc. & $\#$ & Label & Oc. \\
\hline 1 & entrepreneurship & 32 & 22 & environment & 4 \\
\hline 2 & sustainable development & 20 & 23 & finance & 4 \\
\hline 3 & innovation & 11 & 24 & institutional theory & 4 \\
\hline 4 & competitive advantage & 9 & 25 & knowledge management & 4 \\
\hline 5 & globalisation & 9 & 26 & marketing & 4 \\
\hline
\end{tabular}


A Mixed Methods Bibliometric Investigation of the World Review of Entrepreneurship, Management and Sustainable Development: from qualitative to quantitative data

\begin{tabular}{|c|l|c|c|l|c|}
\hline 6 & management & 9 & 27 & productivity & 4 \\
\hline 7 & sustainability & 8 & 28 & tourism & 4 \\
\hline 8 & corporate governance & 6 & 29 & corruption & 3 \\
\hline 9 & $\begin{array}{l}\text { corporate social } \\
\text { responsibility }\end{array}$ & 6 & 30 & economic development & 3 \\
\hline 10 & economic growth & 6 & 31 & efficiency & 3 \\
\hline 11 & internationalisation & 6 & 32 & ethnicity & 3 \\
\hline 12 & SMEs & 6 & 33 & family & 3 \\
\hline 13 & competitiveness & 5 & 34 & growth & 3 \\
\hline 14 & CSR & 5 & 35 & healthcare system & 3 \\
\hline 15 & culture & 5 & 36 & HRM & 3 \\
\hline 16 & family business & 5 & 37 & innovation management & 3 \\
\hline 17 & foreign direct investment & 5 & 38 & leadership & 3 \\
\hline 18 & human resource & 5 & 39 & spirituality & 3 \\
\hline 19 & performance & 5 & 40 & technology & 3 \\
\hline 20 & strategy & 5 & 41 & technology transfer & 3 \\
\hline 21 & education & 4 & 42 & venture capital & 3 \\
\hline
\end{tabular}

Table 9 Keywords distribution legend

\begin{tabular}{|l|c|}
\hline Keywords & Cluster \\
\hline $\begin{array}{l}\text { competitive advantage, finance, innovation management, } \\
\text { marketing, performance, strategy, tourism, venture capital }\end{array}$ & Red (1) \\
\hline $\begin{array}{l}\text { competitiveness, entrepreneurship, family, family business, } \\
\text { growth, internationalisation, SMEs }\end{array}$ & Blue (3) \\
\hline $\begin{array}{l}\text { corruption, economic development, economic growth, foreign } \\
\text { direct investment, globalisation, sustainable development, } \\
\text { technology transfer }\end{array}$ & Yellow (4) \\
\hline $\begin{array}{l}\text { efficiency, environment, healthcare system, innovation, } \\
\text { knowledge management, productivity, technology }\end{array}$ & Purple (5) \\
\hline $\begin{array}{l}\text { corporate governance, corporate social responsibility, CSR, } \\
\text { institutional theory, sustainability }\end{array}$ & Light Blue (6) \\
\hline culture, education, ethnicity & Dark Blue (7) \\
\hline HRM, human resource management, leadership & Brown (8) \\
\hline management, spirituality
\end{tabular}


Figure 1 Graphical evolution of papers published every year in WREMSD

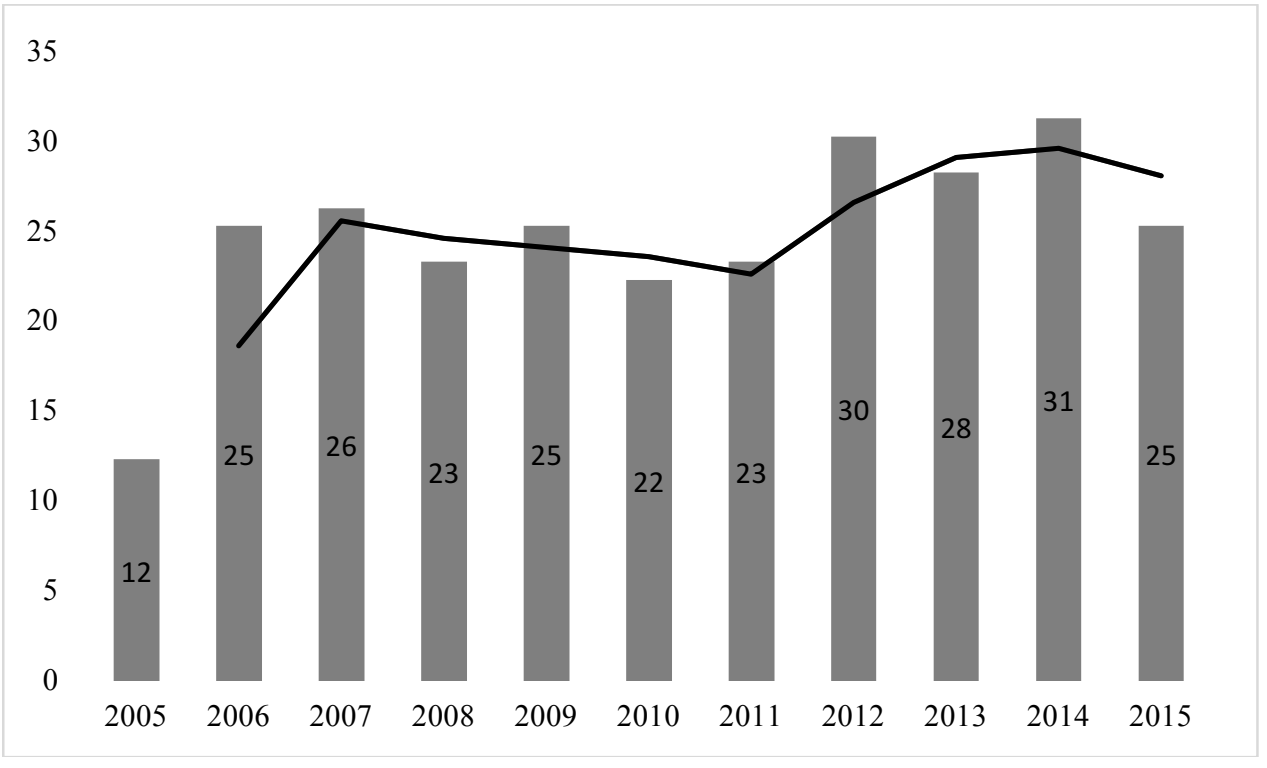

Figure 2 Graphical representation of citation of papers published every year in WREMSD

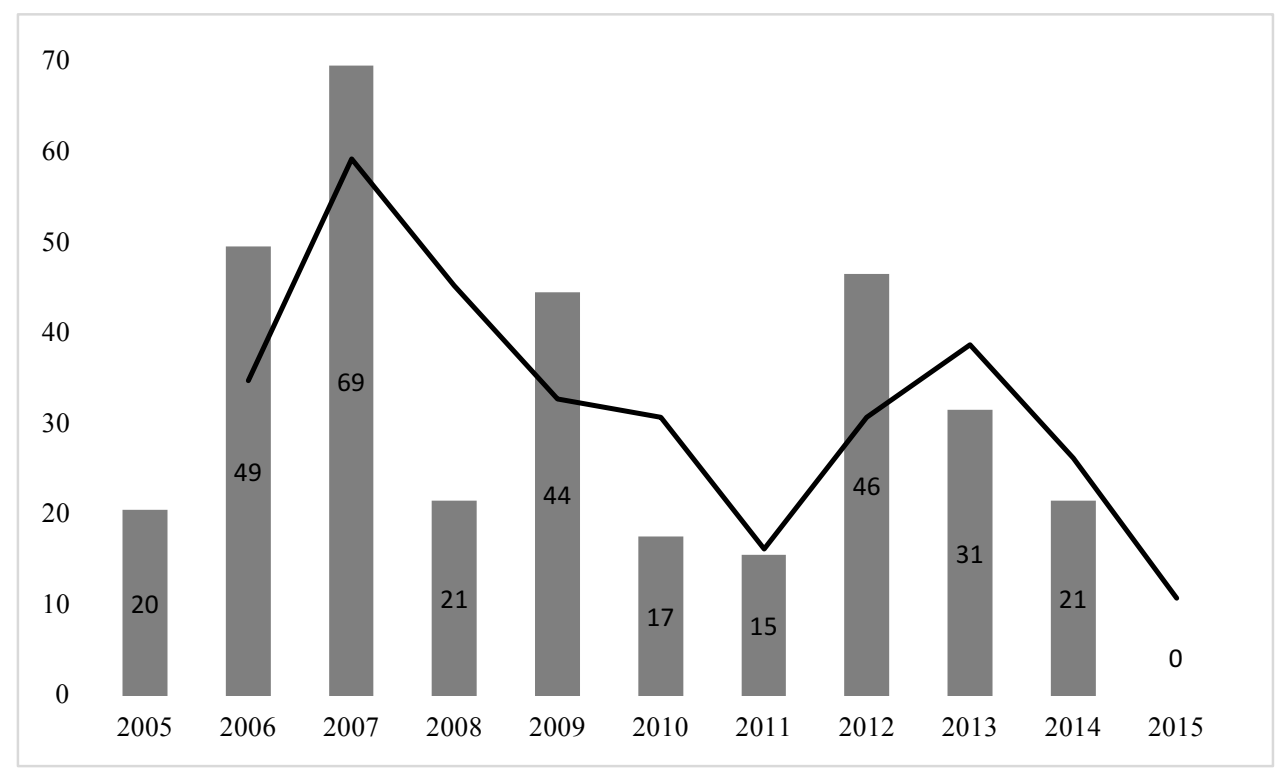


A Mixed Methods Bibliometric Investigation of the World Review of Entrepreneurship, Management and Sustainable Development: from qualitative to quantitative data

Figure 3 Keywords density

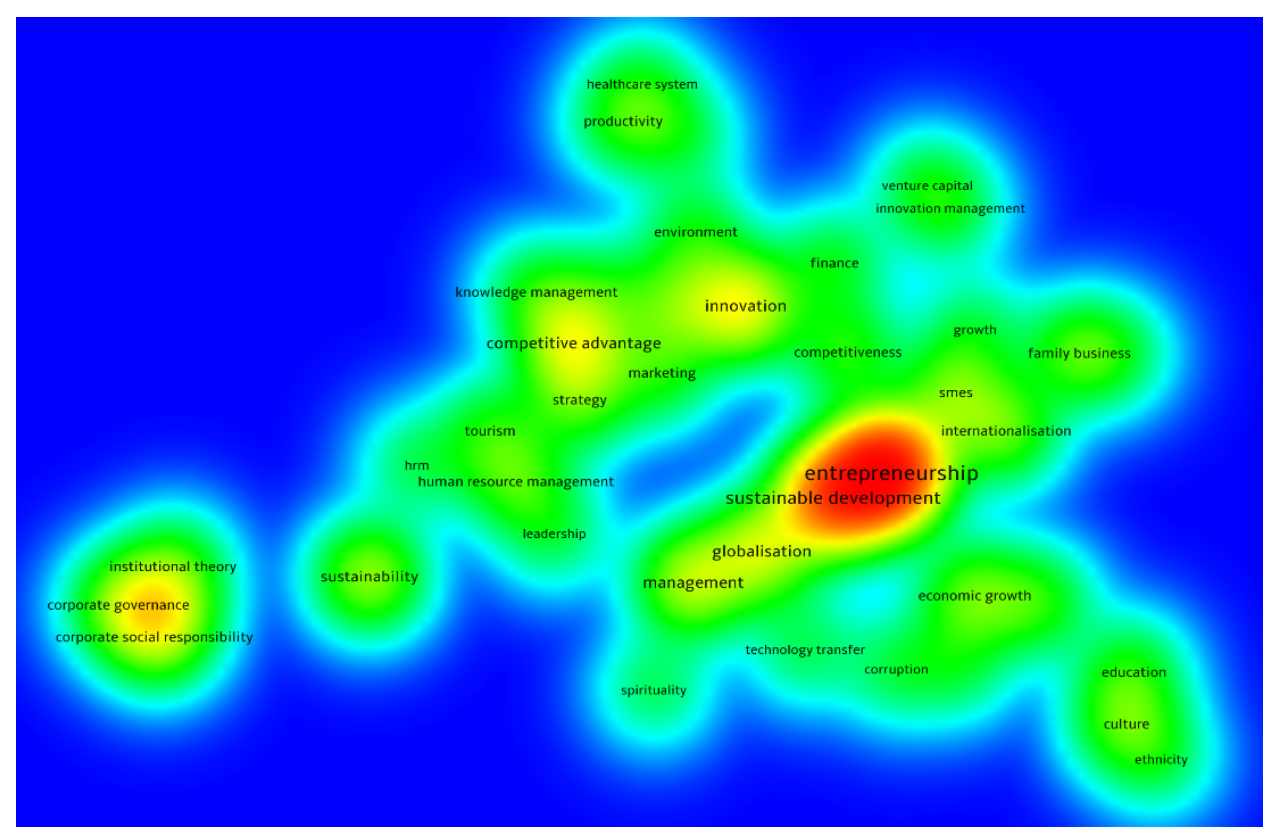

Figure 4 Keywords clusters aggregation

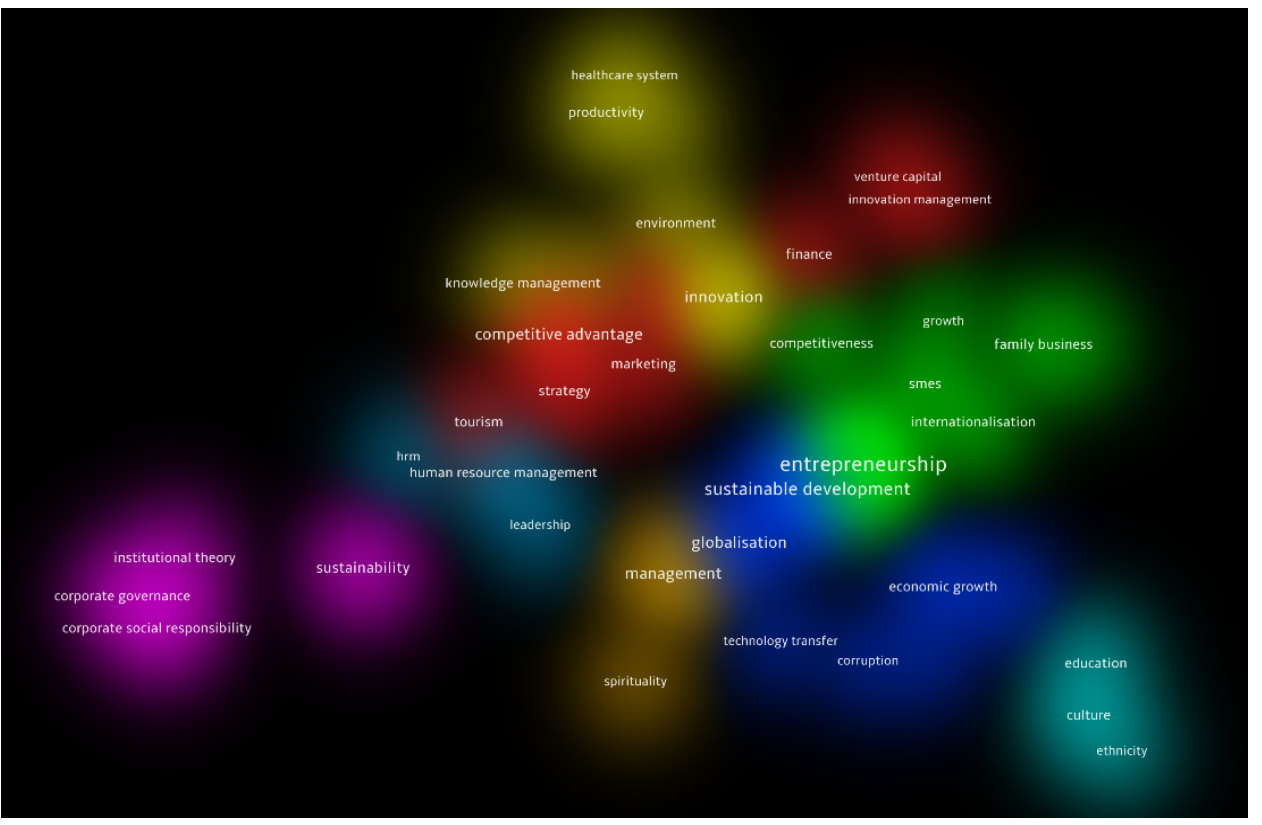

